The EU and Conflict Mitigation in the European Neighborhood: A Story of a Gap Between Ambition and Deeds

Author(s): Zuzana Novakova, Roman Petrov

Source: Kyiv-Mohyla Law and Politics Journal 2 (2016): 1-12

Published by: National University of Kyiv-Mohyla Academy

http://kmlpj.ukma.edu.ua/ 


\title{
The EU and Conflict Mitigation in the European Neighborhood: A Story of a Gap Between Ambition and Deeds
}

\author{
Zuzana Novakova
}

Erasmus University,

International Institute of Social Studies

\section{Roman Petrov}

National University of Kyiv-Mohyla Academy,

Department of International Law,

Jean Monnet Centre of Excellence

\begin{abstract}
From Russia's aggression in Eastern Europe to the aftermath of the Arab Spring in the Southern Mediterranean, conflicts and violence highlight a range of new challenges to the EU's external policy. There were six territorial disputes among the EU's neighbours when the European Neighbourhood Policy was launched 12 years ago. None of these has been resolved, and both the Eastern and the Southern neighbours are more unstable and insecure today than they were when the Policy was launched. The EU seems unprepared to deal with these conflicts, as they now exist. This article analyses the European Neighborhood Policy as a framework for EU involvement in conflict prevention, management and resolution. The focus is twofold: first, on the principle of good neighborliness and the pitfalls preventing its effective implementation and, second, on the wider policy and political context of EU actorness in conflict and security matters.
\end{abstract}

KeyWords: conflict management, conflict prevention, European Union, European Neighborhood Policy, EU leverage, good neighbourliness, security.

\section{(7)}

\section{Crisis as the New Normal for European Neighborhood Policy}

From Russia's aggression in Eastern Europe to the aftermath of the Arab Spring in the Southern Mediterranean, conflict and violence highlight a range of new challenges to the EU's external policy. Twelve years after the establishment of the European Neighbourhood Policy (ENP), the EU faces a region more troubled than ever. None of the conflicts in the neighbourhood in 2004 has been resolved, and both the Eastern and the Southern neighbours are more unstable and insecure today than they were then. Crisis seems to be the new normal in the ENP region. ${ }^{1}$ Does this mean that conflict prevention within the ENP failed to play a role?

1 Nick Witney and Susi Dennison, Europe's Neighbourhood: Crisis as the New Normal (London:

European Council on Foreign Relations Policy Memo, 2015). 
When conceiving the ENP in 2004, policy-makers in Brussels could hardly imagine that 12 years later they would have witnessed almost a dozen revolutions followed by open-ended transitions heading in all sorts of directions, several open wars, persistent frozen conflicts and an annexation within the ENP region. A debate erupted in academia, ${ }^{2}$ as well as in the policy world, ${ }^{3}$ on the ENP's failures in attaining its aims of "strengthening stability, security and wellbeing for all." 4 The prelude to the launch of the renewed ENP in November 2015 was marked by a growing acknowledgement that the ENP's core objective of establishing a "ring of friends" had not been attained. Instead, the metaphor of "ring of fire" is ironically used to depict that many of the 16 countries from Maghreb to Caucasus are in turmoil and that the EU's magnetism might not be sufficient for the flames to fade.

The ENP was not primarily designed as an instrument for conflict management or resolution, despite its links with the European Security Strategy of $2003 .{ }^{5}$ Nevertheless, the EU's policy toward its neighbours has been inseparable from regional conflict. The linkages between this conflict and the ENP's tools are evident in Eastern Europe as well as south of the EU's border. The attention to conflict prevention, management and resolution has gained visibility and rhetorical importance, yet words have not come close to being matched by deeds. The ambition to become relevant in security matters has not been followed by substantial tangible action. ${ }^{6}$

This article scrutinizes the ENP as a framework for EU involvement in conflict prevention, management and resolution. Its first part focuses on the principle of good neighbourliness and the pitfalls in the ENP design that prevent its effective implementation. Its second part looks more closely at the wider policy and political context of EU actorness in conflict and security matters. Here again, it highlights the ENP's inherent limitations, that are central to this article's concluding remarks.

2 Judy Dempsey, Is the European Neighborhood Policy Doomed? (Brussels: Carnegie Europe, 2015); Michael Leigh, A New Strategy for Europe's Neighborhood (Brussels: GMF, 2014); Laurent Beauguitte, Yann Richard and France Guerin-Pace, "The EU and Its Neighbourhoods: A Textual Analysis on Key Documents of the European Neighbourhood Policy," Geopolitics 20 (2015): 853-79.

3 Eg. the Joint Consultation Paper on ENP review open acknowledges that "the ENP has not always been able to offer adequate responses to recent developments, nor to the changing aspirations of our partners. Therefore, the EU's own interests have not been fully served either." Joint Consultation Paper by European Commission and High Representative of the European Union for Foreign Affairs and Security Policy, Towards a New European Neighbourhood Policy (Brussels, 2014).

4 Communication from the European Commission, European Neighbourhood Policy: Strategy Paper, COM (2004) 373 Final (Brussels, 2004).

5 A Secure Europe in a Better World: European Security Strategy, DOC78367/2003 (Brussels, 2003).

6 See eg. European Commission, Strengthening the European Neighbourhood Policy, COM (2006) 726 Final (Brussels, 2006) or European Parliament, Resolution of 23 October 2013 on the European Neighbourhood Policy: Towards a Strengthening of the Partnership (Strasbourg, 2013). 


\section{Good Neighborliness, Neighbors of the Neighbors and the EU Leverage}

An umbrella framework for the EU's relations with its neighbours, the ENP was launched with the aim of establishing "a ring of friends" around the EU's external borders, gradually leading to their "sharing everything but institutions." 7 By fostering an ever-closer relationship between the EU and its partner countries, it aims at "contributing to an area of security, prosperity and good neighbourliness." ${ }^{8}$ In practical terms this implies political association and deeper economic integration, increased mobility and more people-to-people contacts within each of the 16 partner countries of the EU's geopolitically delineated neighbours. ${ }^{9}$ Out of these, some neighbour Europe's borders more than others, and (for varying reasons) the ENP's scope excludes Turkey and Russia.

The ENP's primary format is a series of bilateral relations, guided by formally institutionalized individual Action Plans and supported by a multitude of instruments derived from the procedural logic of the EU's enlargement policy. The bilateral track of relations is then complemented to a lesser degree by two multilateral forums, the Union for the Mediterranean and the Eastern Partnership. ${ }^{10}$

The ENP builds on the Wider Europe Communication ${ }^{11}$ and the Strategy Paper on the ENP, ${ }^{12}$ both of which were developed in the run-up to the EU's big-bang enlargement of 2004. As this timeframe suggests, the ENP was designed when the neighbourhood was more stable than it is now. As originally a product of its time, it had to be reviewed repeatedly in reaction to changing circumstances. The ENP has undergone four to five such reviews ${ }^{13}$ aimed mainly at improving its implementation and programming. The launch of the two multilateral forums can also be understood as a further consolidation of the EU's approach to these regions.

Romano Prodi, "A Wider Europe - A Proximity Policy as the Key to Stability" (speech presented at the Sixth ECSA-World Conference "Peace, Security and Stability International Dialogue and the Role of the EU," Brussels, December 5-6, 2002).

8 Joint Communication to the European Parliament, the Council, the European Economic and Social Committee and the Committee of the Regions, Neighbourhood at the Crossroads: Implementation of the European Neighbourhood Policy in 2013 (Brussels, 2013).

9 The launch of the ENP was initially intertwined with the European Security Strategy of 2003, with stabilization of the "near abroad" as the most exigent geopolitical challenge facing the EU, envisioning "a better ring of friends" at the European external borders. A year later the ENP became an umbrella framework for relations, providing a label for resource commitment, a degree of political visibility and "branding" for EU's relations and action vis-à-vis the "neighbouring" countries.

10 Launched at the Paris Summit in July 2008 and at the Prague Summit in May 2009 respectively.

11 Communication From The Commission To The Council And The European Parliament, Wider Europe - Neighbourhood: A New Framework for Relations with our Eastern and Southern Neighbours, $\operatorname{COM}(2003) 104$ Final (Brussels, 2003).

12 Communication from the Commission, European Neighbourhood Policy Strategy Paper, COM (2004) 373 Final (Brussels, 2004).

13 For detailed discussion see Zuzana Novakova, A New Strategy for Europe's "Near Abroad"? Review of the EU Neighbourhood Policy in wider context (Kyiv: East European Security Initiative, 2015). 
The principles of conflict prevention and good neighbourliness were built into the ENP. They follow on article 8 (1) of the Treaty on the Functioning of the European Union, which stipulates that the EU "shall develop a special relationship with neighbouring countries, aiming to establish an area of prosperity and good neighbourliness, founded on the values of the Union and characterised by close and peaceful relations based on cooperation." At the time of the ENP's launch, six protracted conflicts persisted within and between the EU neighboring countries. ${ }^{14}$ Accordingly, the Action Plans for each of the countries involved in these territorial disputes listed conflict resolution among the priority areas for cooperation. The priority ranking, however, differed from country to country, from a relatively low ranking for Morocco to the first priority for Azerbaijan. The interpretation of the content and scope of the ENP's principles of conflict prevention and good neighbourliness belongs exclusively to the EU institutions; hence, this priority area was not a traditional component of the annual ENP progress reports.

The principle of good neighbourliness contained in the ENP's founding documents ${ }^{15}$ underpins the objective of settling conflicts between the EU neighboring countries. ${ }^{16}$ They refer to improving security on the EU's borders by settling conflicts between neighbouring countries, thereby recognising the principle of good neighbourliness as a European common value to be shared by all parties to the ENP. ${ }^{17}$ The EU, however, has been frequently accused of oscillating between promotions of values on the one hand and a pragmatic support for status quo in the neighbourhood region on the other. The inconsistent application of the ENP's conditionality principle in different contexts has led to a severance of relations with some countries that diverted from "common values," such as Belarus, but not with others, such as Azerbaijan and Israel. With the 2015 review of the ENP, the stress put on shared values (as well as its support by the principle of conditionality) seemed to progressively fade from the ENP's forefront in favor of a more pragmatic and tailor-made approach.

Formally, the principles of conflict prevention and good neighbourliness complement the ENP's core principles and thereby occupy an important place under the ENP's framework and

14 Abkhazia and South Ossetia (Georgia), Nagorno-Karabakh (Azerbaijan and Armenia), PalestineIsrael, Transnistria (Moldova) and Western Sahara (Morocco).

15 For detailed discussion see Roman Petrov, "Conflict Prevention and Good Neighbourliness in the European Neighbourhood Policy," in Good Neighbourly Relations in the European Legal Context, ed. Dimitry Kochenov et al. (Leiden; Boston, MA: Brill Nijhoff, 2015).

16 Some Association Agreements (AA) - especially between the EU and its eastern neighbours give a prominent place (among the essential elements) to the principle of good neighbourliness. Eg. Article 2 of the EU-Ukraine AA, the EU-Georgia AA and the EU-Moldova AA provide that "Promotion of respect for the principles of sovereignty and territorial integrity, inviolability of borders and independence, as well as countering the proliferation of weapons of mass destruction, related materials and their means of delivery also constitute essential elements of this Agreement." For example, the ENP documents equate the promotion of the settlement of conflicts and the need to develop good neighbourly relations between the EU's neighbouring countries (Communication from the European Commission, European Neighbourhood Policy Strategy Paper, COM (2004) 373 Final (Brussels, 2004)). Nevertheless, the ENP documents did not regard the principles of conflict prevention and good neighbourliness as core principles of the ENP along the principles of differentiation, conditionality and joint ownership. See also footnote 15 . 
the EU's regional policies. In practice, many of the ENP's objectives have not been successfully achieved, including the effective application of the principle of conflict prevention and good neighbourliness. Like much of the ENP's approach, ${ }^{18}$ this principle is derived from the enlargement policy, where it has helped to improve relations between some of the pre-accession countries. ${ }^{19}$ However, principles like the EU enlargement policy operate differently when they are applied through the neighbourhood policy. In the EU's enlargement, the EU's role in conflict prevention and management is based on the premise of inclusion of all parties concerned. The ENP, however, highlights an almost binary inclusion-exclusion dynamic.

The ENP's focus is on the bilateral relationships between the EU and each partner country, relationships in which the differentiation and more-for-more principle lead in practice to relations that diverge in scope and depth. This dynamism has the potential of indirectly and unintentionally increasing the distance between the parties to a regional dispute. ${ }^{20}$ Multilateral cooperation is given far less energy and other resources. ${ }^{21}$ The nature of the bilateral relations limits the space for conflict mitigation, mainly because the principle of ownership requires that any Action Plan be based on a mutual agreement with the partner country on any specific steps vis-à-vis conflict resolution and prevention. When the other side does not share an interest in settling the conflict or the EU's vision on how to do so, the Action Plan is silent on any concrete measures.

The exclusion of other significant regional players, especially the key neighbours of Russia ${ }^{22}$ and Turkey, ${ }^{23}$ remains a serious shortcoming of the whole framework. The ENP seeks to promote

18 The ENP's overall policy design largely borrows from EU's experience. While drawing a clear line to the enlargement, the logic derived from this experience remains pertinent in both content and form of the neighbourhood policy.

Its role in containment of the troubles in relations between Hungary and Slovakia, in light of the membership aspirations of both countries in late 199os, is an often quoted example in this respect. In other words, the progress in economic integration with the EU, such as concluding the AAs and Deep and Comprehensive Free Trade Agreements (DCFTAs), can increase tensions with disputed territory or those whose exports will (as a result of this integration) no longer benefit from the preexisting Autonomous Trade Preferences when the new framework is implemented. The deterioration of relations between Moldova and Transnistria is a fresh example of such unintended consequences, as Transnistria is set to lose trade preferences two years into the implementation of the DCFTA between the EU and Moldova.

21 In terms of financial priorities and density of interactions the multiateral track of ENP is devoted less attention. In an aggregate view of budget allocation under the European Neighbourhood and Partnership Instrument (ENPI), the regional component accounted for $13 \%$ in the South and $26 \%$ in the East. The regional dimension has been slightly growing over time and the trend of gradual increase of EU financial allocations and commitments for regional and cross-border cooperation has been confirmed under the current European Neighbourhood Instrument (ENI), which replaced ENPI as from 2014. Arguably, also other neighbours of the neighbours, particularly in the Gulf region. 
good neighbourly relations only with the EU's neighbouring countries and the EU. The recent developments in Ukraine, Georgia and Armenia have proven that referring to the principle of good neighbourliness in the Eastern Partnership without including Russia remains a structural limitation of the ENP. Not extending the principle beyond the EU neighbourhood implies a sort of a dividing line between the 16 neighbouring countries and the countries that are not covered by the ENP. Excluding key regional and global security players, especially those who are direct neighbours of the EU's neighbours, is unfortunate. Engaging them in the implementation of the principle of good neighbourliness would have mattered symbolically and could have mattered in tangible ways.

The scope of the EU's leverage remains pragmatically questionable because the ENP is based on the enlargement tools and mechanisms in form, yet it is applied in the complete absence of the prospect for EU membership. A stake in EU's internal market through Deep and Comprehensive Free Trade Agreements (DCFTAs) is the ENP's biggest carrot. The enhancement of trade relations though liberalization and the gradual creation of free trade areas was originally conceived, inter alia, as a stabilizing factor. The premise was that increased economic interdependence would reduce the potential for conflict or would be a road to modernization because an economic opening might lead to a political opening, especially in some of the persistently authoritarian regimes. The developments over the last few years, however, have shown that the carrot and its ancillary features have "largely failed to inspire the neighbours, especially those who do not share the Union's values." ${ }^{24}$

The method of exporting acquis communautaire, adherence to EU standards and economic reform were met by a lack of political will in partner countries, since this road incurs social costs in the short-run. Moreover, there are no straightforward mechanisms to compensate the shortand mid-term losers from market integration. When the EU embarked on the common market, ${ }^{25}$ the regions and sectors that lost from this integration in the short-run were "compensated" through regional policy and cohesion funds (and, partly, through the common agricultural policy), all of which helped financially support the costs of economic restructuring. The ENP, however, does not contain mechanisms comparable in scope or size.

Even in the more EU-inclined Eastern Partnership region, the ENP failed to prevent some of the neighbours from withdrawing from the course of European integration. For example, the negotiation of the Association Agreement with Armenia actually worked to further exclude the EU instead of giving it more leverage. This has not been helpful for conflict resolution. Perhaps the EU's ambitions in the region might not have been backed up with adequate leverage in terms of incentives and capabilities. ${ }^{26}$

24 Steven Blockmans, The 2015 ENP Review: A policy in Suspended animation (Brussels: Center for European Policy Studies, 2015).

25 See the Single European Act of 1986.

26 Here one could argue that the vague and ambitious objectives without sufficient technical and financial assistance on behalf of the EU discouraged the neighbouring countries to pursue effective domestic reforms and, in some cases (for example, in Armenia and Ukraine) caused considerable dissatisfaction of national governments with the principle of conditionality and, eventually, led to abrupt U-turn of their external policies from the EU towards alternative integration projects. 


\section{EU, Conflict and Security: The Wider Framework}

Despite the EU's ambition to become relevant in security matters in the neighbourhood, the main security tools - the Common Foreign and Security Policy (CFSP) and the Common Security and Defense Policy (CSDP) - have played a marginal role. The fact that less than one third of the EU's CSDP missions abroad have been deployed in the neighbourhood region illustrates this. Only five neighbours have benefitted from this support, ${ }^{27}$ a relatively low number compared to the priority that the EU gives to its neighbors on other issues.

The EU's overall interaction with its neighbours remains a sort of "institutional hybrid." The depoliticized areas of market integration and aid allocation are driven by bureaucrats of the European Commission and, more recently, the European External Action Service (EEAS), while political action rests primarily upon the agreement of the member states. This institutional structure of the EU's foreign policy, with the strong role it gives to member states, often limits or precludes any concerted (re)action. Thus, member states are often far from speaking with one voice when meeting in the Council. Currently, as the EU continues to muddle through a series of domestic and international crises, the divisions between the member states affect the EU's actions on security within the neighborhood.

These divisions can be seen in the ongoing Ukraine crisis. The EU's reaction involves increasing aid flows to Ukraine; symbolically joining the Contact Group for the Resolution of Ukraine-Russia Crisis (along with the OSCE, Russia, Ukraine and the separatists); establishing the EUAM-EU Advisory Mission for Civilian Security Sector Reform with a relatively narrow advisory mandate and adopting several rounds of (selective) sanctions against Russia. Why not more action or a stronger stance?

Differences among the member states surfaced in reaction to the Russian annexation of Crimea and the outbreak of violent conflict in the Donbas region. So long as different views on the appropriate involvement in this crisis ${ }^{28}$ persist, any action taken will be not greater than any action agreed to by a consensus among the members. Above all else, the differing perspectives on Russia explain the differences among the EU's members on the EU's appropriate

27 CSDP missions deployed in the European neighbourhood since 2003: in Libya (1 military mission, 3 border control missions), in Palestinian territories ( 1 border control mission and 1 police mission), in Georgia (2 civil/rule of law missions), Moldova-Ukraine (a hybrid mission), and within Ukraine ( 1 advisory mission for civilian security sector reform).

28 Looking from a less conventional angle, the current EU approach is in line with citizen preferences within the EU. A swift look at the attitudes of EU citizens suggests agreement with the kind of foreign policy approach pursued within the ENP, when relating to the crisis in Ukraine. According to the Transatlantic trends survey majority of Europeans favor the focus on economic and political support (58\%), without much EU action in the field of defence (for example, only $25 \%$ are in favor of sending military equipment or arms to Ukraine). Around $61 \%$ of Europeans approve the sanctions towards Russia. What is slightly surprising is that almost $52 \%$ of Europeans would agree with offering the ultimate carrot of EU membership to Ukraine if it fulfilled all conditions. (All data based on German Marshall Fund of the United States, Transatlantic Trends Key Findings (Washington and Brussels, 2014).) 
involvement. These differences range from a call for a tough EU position by Poland and the Baltic states ${ }^{29}$ to resistance to actions against Russia from the traditionally more "Russophile" countries of Italy, Greece, and Slovakia. ${ }^{30}$ The latter group also tends to take a more reluctant stance (or even active opposition) to any strengthening of sanctions against Russia. Here, as in any similar situation, any consensus often is the lowest common denominator acceptable for all rather than a strong policy stance.

Therefore, unsurprisingly, the EU is not in the driver's seat of conflict management. The Franco-German locomotive of EU decision-making pragmatically opted to pursue a concrete conflict management initiative, while circumventing the EU level. Germany, with its own Ostpolitik completely undermined by the crisis, found it difficult to foster a strong, unitary EU voice. France faces strong pressure from French industries, many of whose fortunes are tied to the Russian economy. Following their traditional policy focus on cooperating with Russia, both countries maintain their active involvement in the crisis through the Normandy format, leaving a polarized EU to play a secondary role.

By seeking to balance these divisions, the EU has a policy, but its approach has failed on the political level. Consequently, the EU lacks a strategic vision for addressing conflict in its near abroad that would be able to mobilize the much-needed political will of its member states.

\section{Concluding Remarks}

The ENP has become a straightjacket for EU's relations with its neighbours. In all of the ENP's four revisions, the EU responded to new developments by fine-tuning the ENP's toolbox and increasing its financial commitments. Yet it also maintained the shortcomings in the ENP's design that resulted from borrowing too much from the EU enlargement experience.

Conflict resolution is among priority areas for cooperation listed in the Action Plans. The principle of good neighbourliness contained in the ENP's founding documents underpins the ENP's objective of settling conflicts between neighbours involved in territorial disputes. Yet the policy was unprepared to deal with the conflicts that arose over the 12 years that followed

29 Poland and the Baltic states share a deep distrust in Russia: for the Baltic states the crisis in Ukraine represents one of the biggest foreign policy challenges since their independence. Consequently they voice frustration of slow decision-making on the EU side and call for membership prospects for Ukraine (along with Sweden).

In Italy the historical Italy-Russia bond (economic, later political) has been embraced by both centre-right and centre-left of the political spectra. In Greece an idea of common European security community including Russia permeated all Greek governments since 199os and the country is currently the most "pro-Russian" EU member state (as confirmed by Transatlantic survey 2014, see footnote 28 ). Slovakia, which aspires to maintain friendly pragmatism in relations with Russia mainly in light of its high energy dependency, coordinates positions against the sanctions (together with Hungary and Czech Republic) within the Visegrad group. 
the ENP's creation. Even today, the ENP remains more of an architectural design for building a fireproof house offered to partner countries constantly fighting flames than anything else. ${ }^{31}$

Several interlinked reasons thwart the EU's rhetoric from attaining tangible results. Foremost is ENP's (geographic) scope, which is an inclusion-exclusion binary that excludes some of the crucial actors in the region, most notably Russia and Turkey. Furthermore, the EU's leverage remains questionable, vis-à-vis the fading interest in some partner countries. The vision of economic reform, of harmonization with acquis communautaire and, ultimately, of inclusion in EU's internal market remains the ENP's biggest carrot. This begets the question, however, of whether the (deep and comprehensive) free trade area is a sufficient finalité for a policy that expects partner countries to pursue unpopular compromises and costly reforms.

A related element is the EU actorness in conflict mitigation in the neighbourhood through the Common Foreign and Security Policy (CFSP) and Common Security and Defense Policy (CSDP). Given the attention that the EU devotes to its immediate neighbors, the use of the CSDP in this region is strikingly limited. ${ }^{32}$ Very few CSDP missions have been operating in the five neighbourhood countries compared to the overall number of 32 CSDP missions launched worldwide. The gap between the neighbourhood's prioritization under the ENP framework and the EU's relatively low activity through the CSFP/CSDP in this region results from an institutional framework in which the "depoliticized" areas of market integration and aid allocation are driven by bureaucrats of the European Commission (and, more recently, the EEAS), while political action depends on a consensus of member states. Unfortunately, this consensus often demarks the lowest common denominator acceptable by all member states rather than a strong policy stance. As every crisis situation in the neighbourhood reminds us, a solid and unitary EU foreign policy worthy of its name is presumptively unlikely.

It remains to be seen what will change in light of the implementation of the "renewed" ENP. ${ }^{33}$ Transitioning the renewed approach from paper into practice remains an open-ended process. Any further developments are likely to be shaped in light of the reviewed EU's Global Strategy introduced by the European External Action Service in June 2016. ${ }^{34}$

\section{Bibliography}

A Secure Europe in a Better World: European Security Strategy, DOC78367/2003. Brussels, 2003. Accessed February 28, 2016. https://www.consilium.europa.eu/uedocs/cmsUpload/ 78367.pdf.

31 Referring to the metaphor introduced by Nicu Popescu and Andrew Wilson, The Limits of Enlargement-lite: European and Russian Power in the Troubled Neighbourhood (London: European Council for Foreign Relations, 2009). One third of the "Global Europe" section of the EU budget is devoted to the 16 neighbourhood countries.

33 Joint Communication to the European Parliament, the Council, the European Economic and Social Commission, Review of the European Neighbourhood Policy, JOIN (2015) 50 Final (Brussels, 2015). European External Action Service, Strategic Review - The European Union in a Changing Global Environment, a review of EU Global Strategy on Foreign and Security Policy. 
Blockmans, Steven. The 2015 ENP Review: A Policy in Suspended Animation. Brussels: Center for European Policy Studies, 2015. Accessed February 21, 2016. www.ceps.eu/system/files/ SB\%2oENP\%2oReview\%2oCEPS\%2oCommentary.pdf.

Beauguitte, Laurent et al. "The EU and Its Neighbourhoods: A Textual Analysis on Key Documents of the European Neighbourhood Policy." Geopolitics 20 (2015): 853-79.

Communication from the European Commission. European Neighbourhood Policy: Strategy Paper, COM (2004) 373 Final. Brussels, 2004. Accessed February 26, 2016. http://eur-lex. europa.eu/LexUriServ/LexUriServ.do?uri=COM:2004:0373: FIN: EN: PDF.

Communication from the European Commission to the Council and the European Parliament. Wider Europe - Neighbourhood: A New Framework for Relations with our Eastern and Southern Neighbours, COM (2003) 104 Final. Brussels, 2003. Accessed February 26, 2016. https://eeas.europa.eu/enp/pdf/pdf/como3_104_en.pdf.

Dempsey, Judy. Is the European Neighborhood Policy Doomed. Brussels: Carnegie Europe, 2015. Accessed February 21, 2016. http://carnegieeurope.eu/strategiceurope/?fa=6o138.

European Commission. Strengthening the European Neighbourhood Policy, COM (2006) 726 Final. Brussels, 2006. Accessed February 26, 2016. http://ec.europa.eu/world/enp/pdf/ como6_726_en.pdf.

European External Action Service. Strategic Review - The European Union in a Changing Global Environment. Ongoing review of EU Global Strategy on Foreign and Security Policy. Accessed February 28, 2016. http://www.eeas.europa.eu/top_stories/2015/150627_eu_ global_strategy_en.htm.

European Parliament. Resolution of 23 October 2013 on the European Neighbourhood Policy: Towards a Strengthening of the Partnership. Strasbourg, 2013. Accessed February 28, 2016. www.europarl.europa.eu/sides/getDoc.do?type=TA\&reference=P7-TA-2013-0446\& language $=\mathrm{EN}$.

German Marshall Fund of the United States. Transatlantic Trends Key Findings, 2014. Accessed February 21, 2016. http://trends.gmfus.org/files/2012/og/Trends_2014_complete.pdf.

Joint Communication to the European Parliament, the Council, the European Economic and Social Committee and the Committee of the Regions. Neighbourhood at the Crossroads: Implementation of the European Neighbourhood Policy in 2013. Brussels, 2013. Accessed February 28, 2016. http://eeas.europa.eu/enp/pdf/2014/joint_communication_en.pdf

Joint Communication to the European Parliament, the Council, the European Economic and Social Commission. Review of the European Neighbourhood Policy, JOIN (2015) 50 Final. Brussels, 2015. Accessed February 28, 2016. http://eeas.europa.eu/enp/ documents/2015/151118_joint-communication_review-of-the-enp_en.pdf

Joint Consultation Paper by European Commission and High Representative of the European Union for Foreign Affairs and Security Policy. Towards a new European Neighbourhood Policy. Brussels, 2014. Accessed February 26, 2016. http://ec.europa.eu/enlargement/ consultation/consultation.pdf.

Leigh, Michael. A New Strategy for Europe's Neighborhood. Brussels: GMF, 2014. Accessed February 21, 2016. http://www.gmfus.org/publications/new-strategy-europe $\% \mathrm{E} 2 \% 80 \%$ 99s-neighborhood. 
Novakova, Zuzana. A New Strategy for Europe's "Near Abroad"? Review of the EU Neighbourhood Policy in Wider Context. Kyiv: East European Security Initiative, 2015. Accessed March 1, 2016. http://eesri.org/2015/11/a-new-strategy-for-europes-near-abroad.

Petrov, Roman. "Conflict Prevention and Good Neighbourliness in the European Neighbourhood Policy." In Good Neighbourly Relations in the European Legal Context, edited by Dimitry Kochenov and Elena Basheska, 289-305. Leiden; Boston, MA: Brill Nijhoff, 2015.

Prodi, Romano. "A Wider Europe - A Proximity Policy as the Key to Stability." Speech at the Sixth ECSA-World Conference "Peace, Security and Stability International Dialogue and the Role of the EU." Brussels, December 5-6, 2002. Accessed February 26, 2016. http:// europa.eu/rapid/press-release_SPEECH-o2-619_en.htm.

Popescu, Nicu, and Andrew Wilson. The Limits of Enlargement-lite: European and Russian Power in the Troubled Neighbourhood. London: European Council for Foreign Relations, 2009. Accessed February 23, 2016. http://ecfr.3cdn.net/befa7od12114c3c2bo_hrm6bv2ek.pdf.

Witney, Nick, and Susi Dennison. Europe's Neighbourhood: Crisis as the New Normal. London: European Council on Foreign Relations Policy Memo, 2015. Accessed February 23, 2016. http://www.ecfr.eu/page/-/Europes_Neighbourhood.pdf.

Zuzana Novakova was a Visiting Research Fellow at Jean Monnet Centre of Excellence at the Kyiv-Mohyla Academy (2015-2016). She is a PhD candidate at Erasmus University Rotterdam (Netherlands), where her research focuses on EU policy responses to societal transitions in the European neighborhood and the nexus between democracy promotion, security and crises management. She also works in the editorial office of the European Political Science Review journal (European Consortium for Political Research and Cambridge University Press), is an associate expert at the East European Security Initiative (Ukraine) and a FutureLab Europe fellow at the European Policy Centre in Brussels (Belgium). In the past she studied at Comenius University (Slovakia), Institut Barcelona d'Estudis Internationals (Spain), Institute of Social Studies in the Hague (Netherlands) and worked in the think-tank sphere for the European Policy Centre (EPC, Belgium) and Centre for the Research of Ethnicity and Culture (CVEK, Slovakia).

Prof. Dr. Roman Petrov lectured Jean Monnet Module in EU law at the Donetsk National University (2001-2004) and conducted post-doctoral research as Max Weber Fellow at the European University Institute (Italy, 2006-2008) and had visiting fellowships at Heidelberg University (Germany) (Alexander von Humboldt fellowship), University of Oxford (UK), Ghent University (Belgium). Prof. Dr. Petrov is founder and first elected President of the Ukrainian European Studies Association (http://jmce.ukma.kiev.ua/uk/uaes) and Head of the Jean Monnet Centre of Excellence in European Studies (http://jmce.ukma.kiev.ua). Areas of Prof. Dr. Petrov's research and teaching include EU Law, EU External Relations Law; Approximation and Harmonization of Legislation in the EU; Rights of Third Country Nationals in the EU, EU-Ukraine Association, Legal Aspects of Regional Integration in the Post-Soviet Area. Since September 1, 2015, Prof. Petrov is Head of the Department of International Law at the National 
University of Kyiv-Mohyla Academy. He is Foreign Chair at the Ghent University (Belgium) in 2015-2016 and Visiting Professor at Latvia University (Latvia) and Augsburg University (Germany). 